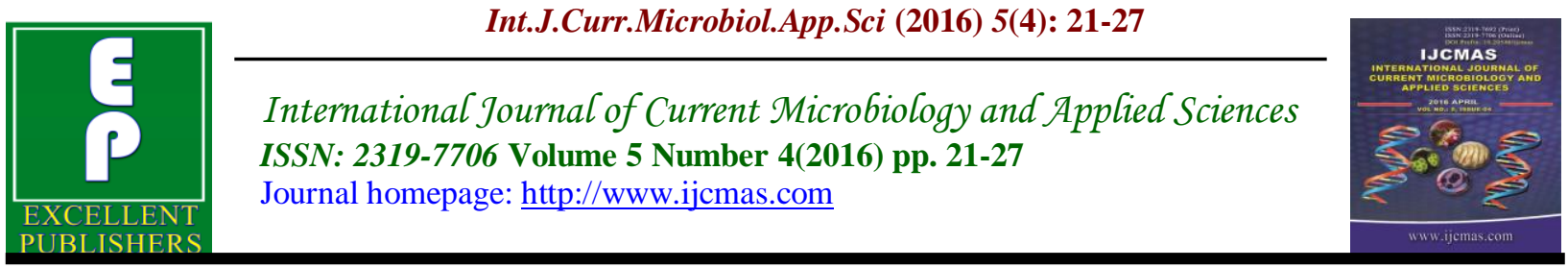

Original Research Article

http://dx.doi.org/10.20546/ijcmas.2016.504.004

\title{
Invitro Antimicrobial Activity of Leaf extracts from Sesbania grandiflora
}

\author{
P. Sarasu Packiyalakshmi*, R. Premalatha and A. Saranya \\ Department of Microbiology and Biochemistry, Nadar Saraswathi College of Arts and Science, \\ Theni - 625 531, Tamil Nadu, India \\ *Corresponding author
}

\begin{abstract}
A B S T R A C T
Keywords

Sesbania grandiflora, Phytochemicals, Antibacterial activity, Minimum inhibitory concentration (MIC).

Article Info

Accepted:

08 March 2016

Available Online:

10 April 2016

Sesbania grandiflora Linn belonging to family Leguminosae is a well-recognized medicinal plant in numerous countries like India, Srilanka and Southeast Asia. The present study examines the phytochemical constituents and antibacterial activity of leaves of Sesbania grandiflora. The quantitative examination of numerous phytochemicals was analyzed in different solvent systems. Antibacterial activities of leaves of Sesbania grandiflora was analyzed through well diffusion technique. Current outcome shows the rich amount of phytochemical constituents present in the leaves. Among the three extracts ethanol showed the maximum activity against Staphylococci $s p$ compared to gram negative bacteria. Minimum inhibitory concentration the least value of the range between $320 \mathrm{~mm}$ to $488 \mathrm{~mm}$ indicated the high activity. Maximum activity recorded against Staphylococci sp for ethanol leaf extract was $316 \mathrm{~mm}$. This proved that Sesbania grandiflora leaves exhibit the highest activity.
\end{abstract}

\section{Introduction}

Plant materials are main sources to treat serious diseases in the world. So far a systematic study of plants to determine their antimicrobial active compounds is a comparatively new field. Sesbania grandiflora is a small tree in the genus Sesbani. It is a fast-growing shrub highly distributed in tropic and subtropics. The selected green leafy vegetable Sesbania grandiflora has various traditional uses. Leaves are used as tonic, diuretic, laxative, antipyretic, chewed to disinfect mouth and throat. Leaves are chewed to purify mouth and throat and are beneficial in stomatalgia (Nadkarni et al., 2009).
Flower is used to treat the headache, dimness of vision, Catarrh, and also used to improve appetite, antipyretic. Bark is used for bitter tonic for anthelmintic, febrifuge, diarrhea, small pox, Astringent. Fruits are used in case of fever, pain, bronchitis, anemia, tumors, colic, jaundice, poisoning (Kirthikar et al., 1998). Root issued in Rheumatism, Expectorant, Painful swelling. Warrier et al. (1996). Sesbania grandiflora is an easily available plant and based on the medicinal properties the present study investigates the phytochemical constituents and antibacterial activity of leaves of Sesbania grandiflora. 


\section{Materials and Methods}

\section{Collection of Plant Samples}

The fresh leaves of Sesbania grandiflora were concurrently collected from open fields of Theni district. The leaves were rinsed thrice with distilled water followed by double distilled water to remove the dust and other contaminants then dried at room temperature.

The methanolic extracts of the Fenugreek Leaf extracted previously were screened for phytochemicals.

For phytochemical analysis, the extracts were prepared by taking each dried powder into separate $100 \mathrm{ml}$ conical flask. To this $50 \mathrm{ml}$ of each solvent (Aqueous, Methanol, ethanol) was added. The conical flasks were allowed to stand for 24hours and then filtered using what man No.1 filter paper. Thus, the filtrates gained were used as test solutions.

The plant extracts were tested for the presence of bioactive compounds by standard method (Yadha et al., 2011)

\section{Test for Carbohydrates}

The presence of carbohydrates in solvent extracts was determined by different methods such as, Fehling's test, Benedict's test, Molisch's test and iodine test.

a) Fehling's test: equal volume of Fehling's reagent $\mathrm{A}$ and $\mathrm{B}$ mixed together and $2 \mathrm{ml}$ of

Mixture was added to plant extracts followed gentle heat, the mixture turned

Brick red color.

(b) Benedict's test: $2 \mathrm{ml}$ of Benedict's solution was added to crude plant extracts followed.

Gentle boiling gives reddish brown precipitate.

(c) Molisch's test: $2 \mathrm{ml}$ of Molisch's reagent was added in plant extract followed

By addition of $\mathrm{H} 2 \mathrm{SO} 4$ which develops the appearance of violet rings in the interphase.

(d) Iodine test: $2 \mathrm{ml}$ of iodine solution added in plant extract gives development of

Dark blue color. Simultaneously, presence of phenols and tannins were tested. $2 \mathrm{ml}$ of $2 \%$

Of $\mathrm{FeCl} 3$ solution were added in the plant extracts. Dark green color was developed for phenolic compounds and black color for presence of tannins

\section{Alkaloids}

The identification of alkaloids was carried out using the Mayer's test. A portion of the plant extract was mixed with $5 \mathrm{ml}$ of sulphuric acid in $50 \%$ ethanol. $1 \mathrm{ml}$ of Mayer's reagent was added drop by drop. The formation of a greenish color or cream precipitate indicated the presence of alkaloids.

\section{Flavonoids}

The identification of Flavonoids was carried out using the sodium hydroxide test. $5 \mathrm{ml}$ of plant extract was mixed with few magnesium chips and 2 drops of concentrated hydrochloric acid were added and warmed. The presence of a pink/red color indicated the presence of flavonoids.

\section{Tannins}

Tannins were identified using the Bromine 
Water test. $5 \mathrm{ml}$ of plant extract was extracted with $20 \mathrm{ml}$ of $50 \%$ alcohol and then filtered. A few drops of bromine water were added to the resulting filtrate. The formation of a buff/white precipitate indicated the presence of tannins.

\section{Saponins}

Saponins were identified via the frothing test. $3 \mathrm{ml}$ of the plant extract was added to $10 \mathrm{ml}$ distilled water and shaken vigorously for 30 seconds. Froth formation indicates the presence of saponins.

\section{Terpenoids}

The identification of terpenoids was performed using Noller's test. The test plant extract was warmed along with a tin piece and 3drop of thionyl chloride. Terpenoids are present if the solution turned a purplish colour.

\section{Steroids}

Finally the presence of steroids was detected using the Libermann-Burchard test. $2 \mathrm{ml}$ of the test plant extract were mixed with 2 drops of chloroform and $2 \mathrm{ml}$ of acetic anhydride, along with $1 \mathrm{ml}$ of concentrated sulphuric acid added down the side of the tube. The formation of a reddish ring at the contact zone of the two liquids and a greenish color in the separate layer indicates the presence of steroids.

\section{Test for Glycosides}

$2 \mathrm{ml}$ of chloroform, $2 \mathrm{ml}$ of acetic acid were added to plant extract and allowed to cool, followed by addition of $2 \mathrm{ml}$ of concentrated $\mathrm{H} 2 \mathrm{SO} 4$ changes the violet to blue then green, indicates the presence of steroidal nucleus that is glycone portion of glycoside. In another way, the available cardiac glycosides are tested by addition of 1-2 drops of glacial acetic acid and $2 \%$ of $\mathrm{FeCl} 3$ solution in crude plant extract followed by $2 \mathrm{ml}$ of $\mathrm{H} 2 \mathrm{SO} 4$, gives brown ring at the interphase indicates the presence of cardiac glycosides.

\section{Qualitative Analysis of Reducing Sugars}

$1 \mathrm{ml}$ of the extract was added with $2 \mathrm{ml}$ of Fehling's reagent and $3 \mathrm{ml}$ of water. It was then boiled for 2 minutes.

\section{In vitro Antibacterial Studies}

\section{Test Organism}

The following bacterial strains were obtained from the laboratory of Department of Microbiology, Nadar Saraswathi College. Gram negative bacterial strain Escherichia coli, Pseudomonas sp, Klebsiella sp and gram positive strain Staphylococcus $s p$, Bacillus $s p$ were used for the present study. They were maintained at $4^{\circ} \mathrm{c}$ on the slants of nutrient agar medium for further use.

\section{Well Diffusion Method}

\section{Muller Hinton agar Formula and preparation}

Muller Hinton agar medium was employed for well diffusion sensitivity testing. The medium contained per litter, infusion from $300 \mathrm{~g}$ beef, $17.5 \mathrm{~g}$ casein hydro lysate, $1.5 \mathrm{~g}$ starch and 17g agar (Monica, 1985). The medium was prepared by dissolving the dehydrated mixture of ingredients in distilled water. After boiling $\mathrm{pH}$ was adjusted to 7.4 and sterilized by autoclaving at $121^{\circ} \mathrm{c}$ for 15 minutues. The medium was poured into the petriplates

\section{Experimental Procedure}

The three solvent extracts were screened against a number of selected pathogenic 
bacteria by agar well diffusion. In this method, 10ml aliquots of nutrient broth were inoculated at $37^{\circ}$ cfor 24 hours. Sterile cotton swabs were dipped in the bacterial suspension and evenly streaked over the entire surface of the agar plate to obtain uniform inoculums. Six wells per plate were made with the reverse side of a sterilized micropipette. $25 \mathrm{ml}, 50 \mathrm{ml}, 75 \mathrm{ml}, 100 \mathrm{ml}$ of different extract were then poured into the respective wells using a micropipette. Distilled water was used as negative control. All plates were incubated for 24hours at $37^{\circ} \mathrm{c}$. The antibacterial activity was determined by measuring the diameter of the zone of inhibition to the nearest $(\mathrm{mm})$ that observed from the clear zone surrounding the well (Ragahavendra et al., 2010).

\section{Determination of Minimum Inhibitory Concentration}

The MIC of the extracts was determined according to the macro broth dilution technique (NCCLS, 2010).Standardized suspensions of the test organisms existed inoculated into a series of sterile tubes of nutrient broth containing two-fold dilution of leaf extracts and incubated at $37^{\circ} \mathrm{C}$ for 24h. MICs were read as the least concentration that inhibited the growth of the test organisms.

\section{Result and Discussion}

The powdered leaves of Sesbania grandiflora extracted with different solvent. The plant extract was then performed for identify the numerous phytochemical constituents.

Phytochemical analysis showed the presence of alkaloids, flavonoids, saponins, glycosides and steroids. Maximum antibacterial activity was observed due to presence of secondary metabolites. All the extracts from Sesbania grandiflora display antibacterial activity against all tested strains. Test for concentration ranging from $25 \mathrm{mg} / \mathrm{ml}$, $\quad 50 \mathrm{mg} / \mathrm{ml}$, $\quad 75 \mathrm{mg} / \mathrm{ml}$, and $100 \mathrm{mg} / \mathrm{ml}$ antibacterial activity tested for well diffusion method. Ethanol extracts showed the maximum zone of inhibition on all organisms especially Staphylococcus sp $(19.3 \mathrm{~mm}$ at $75 \mu \mathrm{l})$. The result was conformed with reports of $\mathrm{K}$. Padmalochana et al., (2014).same result we found in the present investigation.

Table.1 Pnytochemical Constitunts of Sesbania grandiflora

\begin{tabular}{|l|l|l|l|}
\hline Compound & Methanol & Ethanol & Aqueous \\
\hline Alkaloids & + & + & + \\
\hline Saponins & + & + & + \\
\hline Flavonoids & + & + & + \\
\hline Tannins & + & + & - \\
\hline Amino acid & - & - & - \\
\hline Reducing sugar & + & + & + \\
\hline Carbohydrates & - & + & + \\
\hline Glycosides & + & + & - \\
\hline Phenols & + & + & + \\
\hline Steroids & + & + & + \\
\hline Terpenoids & - & - & - \\
\hline
\end{tabular}


Table.2 Invitro Antimicrobial Activity of Sesbania grandiflora Extract Against Bacillus

\begin{tabular}{|l|l|l|l|l|}
\hline \multicolumn{6}{|l|}{ Zone of diameter(mm) } \\
\hline S.NO & Solvent & Leaf 25 & 50 & 75 \\
\hline 1 & Ethanol & 10 & 12 & 14 \\
\hline 2 & Methanol & 8 & 10 & 14 \\
\hline 3 & Aqueous & 11 & 13 & 14 \\
\hline 4 & Standard & 16 & 18 & 12 \\
\hline
\end{tabular}

Table.3 Invitro Antimicrobial Activity of Sesbania grandiflora Extract Against Staphylococcus $S p$

\begin{tabular}{|l|l|l|l|l|}
\hline \multicolumn{6}{|l|}{ Zone of diameter(mm) } \\
\hline S.No & Solvent & Leaf 25 & 50 & 75 \\
\hline 1 & Ethanol & 13 & 14.5 & 19.3 \\
\hline 2 & Methanol & 11.7 & 13 & 16 \\
\hline 3 & Aqueous & 12.6 & 13.7 & 14.5 \\
\hline 4 & Standard & 18 & 16 & 17 \\
\hline
\end{tabular}

Table.4 Invitro Antimicrobial Activity of Sesbania grandiflora Extract against Pseudomonas sp

\begin{tabular}{|l|l|l|l|l|}
\hline \multicolumn{5}{|c|}{ Zone of diameter(mm) } \\
\hline S.NO & Solvent & Leaf 25 & 50 & 75 \\
\hline 1 & Ethanol & 15 & 13.5 & 14 \\
\hline 2 & Methanol & 13 & 13.5 & 12.8 \\
\hline 3 & Aqueous & 9.5 & 10 & 13.6 \\
\hline 4 & Standard & 14 & 15 & 16 \\
\hline
\end{tabular}

Table.5 Invitro Antimicrobial Activity of Sesbania grandiflora Extract Against E.coli

\begin{tabular}{|l|l|l|l|l|}
\hline \multicolumn{5}{|c|}{ Zone of diameter(mm) } \\
\hline S.NO & Solvent & Leaf $\mathbf{2 5}$ & $\mathbf{5 0}$ & $\mathbf{7 5}$ \\
\hline $\mathbf{1}$ & Ethanol & 10.3 & 12 & 13.8 \\
\hline $\mathbf{2}$ & Methanol & 11.5 & 12.8 & 14 \\
\hline $\mathbf{3}$ & Aqueous & 8.5 & 13 & 15 \\
\hline $\mathbf{4}$ & Standard & 12 & 15 & 17 \\
\hline
\end{tabular}

Table.6 Invitro Antimicrobial Activity of Sesbania grandiflora Extract against Klebsiella sp

\begin{tabular}{|l|l|l|l|l|}
\hline \multicolumn{5}{|l|}{ Zone of diameter(mm) } \\
\hline S.NO & Solvent & Leaf $\mathbf{2 5}$ & $\mathbf{5 0}$ & $\mathbf{7 5}$ \\
\hline $\mathbf{1}$ & Ethanol & 6.8 & 8.5 & 13.4 \\
\hline $\mathbf{2}$ & Methanol & 8.2 & 12 & 14 \\
\hline $\mathbf{3}$ & Aqueous & 6 & 9.6 & 10.7 \\
\hline $\mathbf{4}$ & Standard & 11.4 & 12 & 15 \\
\hline
\end{tabular}


Table.7 Mean MIC (mg / ml)

\begin{tabular}{|l|l|l|l|l|l|l|}
\hline S.NO & Plants & E.coli & Klebsiella & Pseudomonas & Bacillus & Staphylococcus \\
\hline 1 & $\begin{array}{l}\text { Sesbania } \\
\text { grandiflora }\end{array}$ & 0.164 & 0.285 & 0.237 & 0.199 & 0.316 \\
\hline
\end{tabular}

Qualitative Analysis of Phytochemical Analysis

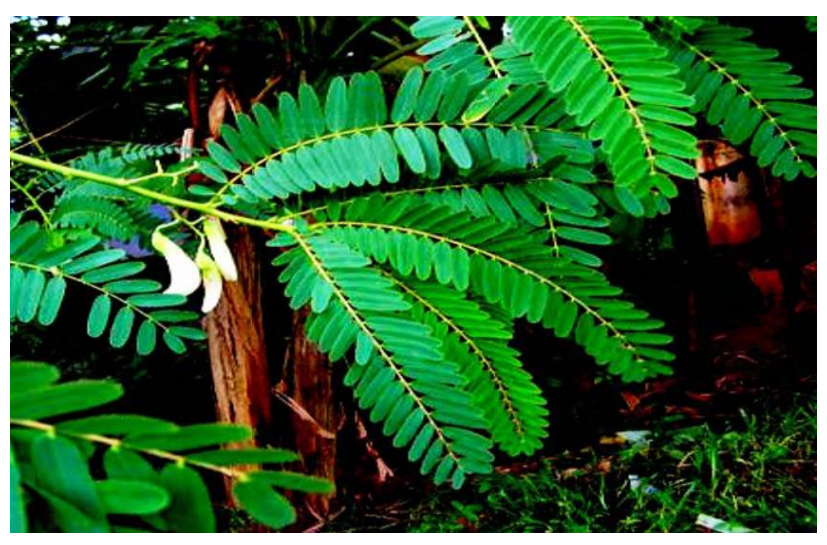

In Vitro Antibacterial Activity of Sesbaniagrandiflora
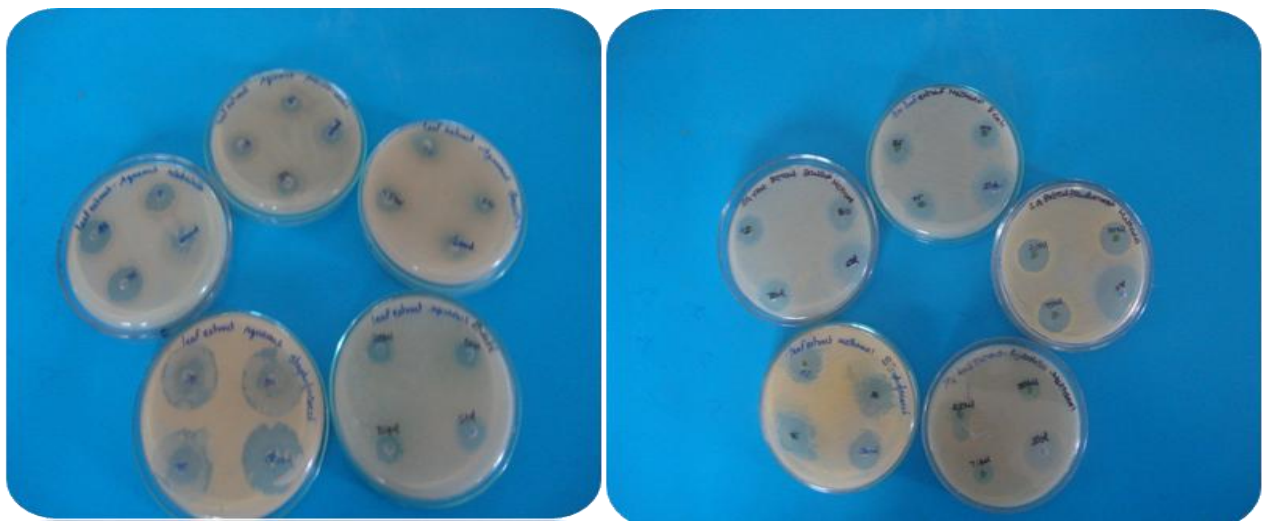

AQUEOUS EXTRACT

METHANOL EXTRACT

Ethanol Extract

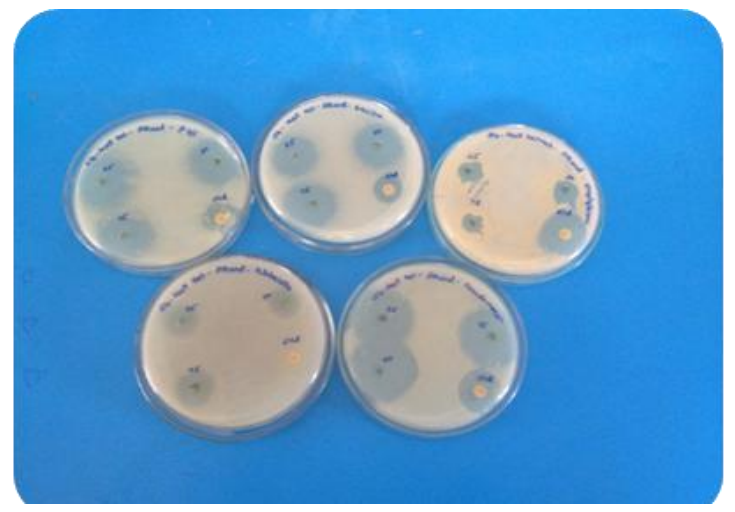


MIC was performed against five organism such as E.coli sp, Klebisiella $s p$, Pseudomonas sp, Staphylococcus sp, Bacillus sp. Minimum inhibitory concentration least value the range between the $320 \mathrm{~mm}$ to $488 \mathrm{~mm}$ indicated the high activity. Maximum activity was recorded for $316 \mathrm{~mm}$ against staphylococcus sp for ethanol leaf extract. This proved that Sesbania grandiflora leaves exhibit the highest activity and so theSesbania grandiflora leaves are potentially used as natural drug.

In conclusion, for this current study, the simple available plant Sesbania grandiflora was selected for the phytochemical screening. Phytochemical analysis showed the presence of alkaloids, flavonoids, saponins, glycosides and steroids. Ethanol extracts showed the maximum zone of inhibition on all organisms especially Staphylococcus sp $(19.3 \mathrm{~mm}$ at $75 \mu \mathrm{l})$ due to presence of secondary metabolites. Based on the results, it is conclude that the ethanol extract of Sesbania grandiflora leaves potentially act as antimicrobial agent.

\section{Acknowledgement}

The project was supported by laboratory of Department of Microbiology \& Biochemistry in Nadar Saraswathi College of Arts \& Science, Theni. I thank the Management, Principal, Head of the Department, Faculty members for their guidance and support.

\section{References}

Nadkarni, A.K. 2009. Indian Materia Medica. Bombay Popular Prakashan, 2nd ed, 52-54.

Prajapti, Purohit, Sharma, Kumar, A. 2003. Handbook of medicinal plants, Agro bios (India), Edition 1st, 473.

Kirtikar，K.R., Basu， B.D. 2005. Indian medicinal Plants Voh, International Book Distributor \& publisher, Dehradun, Edition, 735-736.

Warrier, P.K., Nambiar, V.P.K. Ramankutty, C. 1996. Indian Med. Pl., Vol. 5: 116-117, Madras: Oriental Longman Ltd.

NCCLS. 2000. Methods for Dilution Antimicrobial Susceptibility Test for Bacteria that Grow aerobically; Approved Standard - fifth Edition, NCCLS document M7- A5. NCCLS, Wayne, PA, USA.

Yadha, R.N.S., Agriwala, M. 2011. Phytochemical analysis of some medicinal plants. J. Phyto., 3(12): $10-14$.

Petropoulos, G.A. 2002. Fenugreek the Genus Trigonella. $1^{\text {st }}$ ed., Taylor and Francis, London and New York, 1-4. Raghvendra, D., Kushagra, D., Yasodha, K.J., Jayaveera, K.N. 2010. Comparative antimicrobial a studies of aqueous methanolic and saponins extract of seeds of Trigonella foenumgraecum on Human vaginal pathogens causing UTI infection. Scholars Research Library. Pharma. Chemica, 2(5): 84-88.

\section{How to cite this article:}

Sarasu Packiyalakshmi, P., Premalatha, R. and Saranya, A. 2016. Invitro Antimicrobial Activity of Leaf extracts from Sesbania grandiflora. Int.J.Curr.Microbiol.App.Sci. 5(4): 21-28. doi: http://dx.doi.org/10.20546/ijcmas.2016.504.004 